\title{
Autumn-cut grass silage as roughage component in dairy cow rations. 1. Feed intake, digestibility and milk performance
}

\author{
H. DE VISSER \& V. A. HINDLE
}

DLO-Research Institute for Livestock Feeding and Nutrition, P.O. Box 160, 8200 AD Lelystad, Netherlands

Received 28 November 1991; accepted 10 March 1992

\begin{abstract}
A feeding trial was carried out with 56 dairy cows in second or later lactation. The duration of the experiment was 13 weeks and started immediately after parturition. Basal diets consisted of maize silage, pressed beet pulp, moist ensiled maize gluten feed, ensiled brewers' grains and concentrates, which provided $70 \%$ of total dry matter (DM). The remaining $30 \%$ of the DM consisted of grass silages, which were fed as supplement to the basal diet. Treatments were wilted grass silage (WGS), moist grass silage ensiled with molasses (MGS), moist grass silage ensiled with formic acid (FGS) and wilted grass silage with added water (WW). The rations were fed as a totally mixed ration (TMR) to avoid selection. All grass silages were harvested between August 30th and September 1st from the same pastures. The moist grass silages differed in chemical composition from the wilted grass silage in ash (higher), crude fibre (lower) and NDF (lower). The in vitro and in vivo digestibility did not differ between silages. Total dry matter intake was lowest for both moist silages (MGS and FGS) and as a consequence net energy intake was also lowest with MGS and FGS. Milk production was highest on WGS and WW, resulting from the higher energy intake. Milk fat production and content did not differ between treatments. Milk protein production was significantly lower for groups fed MGS and FGS. Milk protein content tended to be lower for groups fed FGS and MGS. During the experiment energy balance was negative on all treatments.

Calculation of the Duodenal digestible protein value (DVE), using the recommended equation for grass silage, gave for the WGS silage a better fit with the DVE balance measured in the feeding trial, than found with high moisture silages (MGS, FGS), which appeared to be under-estimated. Bodyweight changes corresponded favourably with net energy balances, after correction of energy values for volatiles in grass silages, using individual net energy values for volatiles instead of an average for grass silage OM.
\end{abstract}

Keywords : cow, grass silage, digestibility, intake, milk production, milk composition

\section{Introduction}

During the winter period wilted grass silage is the most important roughage fed 
to dairy cows in the Netherlands. Some of the advantages of wilting include the fact that less moisture has to be transported, a lowering in microbial conversions and a reduction in seepage losses. In some countries, e.g. United Kingdom and Ireland farmers tend to produce moist silages, with or without an additive, due to the climatic conditions which prevail. Several research workers reported good milk performances when feeding high-moisture silages (Gordon, 1980; Burgstaller \& Huber, 1984; Honig et al., 1984). In the Netherlands farmers have harvested wilted grass silage for many years with dry matter contents between 35 and $60 \%$. In order to reduce harvesting losses and to limit the risks from bad weather conditions there is an increasing tendency towards more rapid ensiling techniques, one day wilting with or without additives instead of a 2-3 day wilting period. Changing from wilting to wet ensiling systems increases the amount of fermentation products in the silage (Murphy \& Gleeson, 1984; Donaldson \& Edwards, 1976; Derbyshire et al., 1975). The quality of grass silage with a high-moisture content made without an additive deteriorates rapidly (Castle \& Watson, 1970a, 1970b; Donaldson \& Edwards, 1976), due to seepage, increased respiration losses, high $\mathrm{pH}$ and increased butyric acid levels. The type of additive used can also influence the amount of fermentation end products. Using molasses as an additive increases the amount of fermentation end products, due to fermentation of the available sugars (lactic acid and acetic acid), while addition of formic acid reduces the formation of these products, due to reduced activity of micro-organisms as a result of an increase in acidity. Increases in the amount of carbohydrates fermented to lactic acid and volatile fatty acids during ensiling reduce the amount of energy available to microbes in the rumen for synthesis of microbial protein, according to van Soest (1982) and Miller (1982). Reduction in microbial protein synthesis decreases milk protein percentage and/or production (Robinson et al., 1987; de Visser \& Tamminga, 1987; de Visser \& Hindle, 1990). It was the aim of this study to investigate separately the effects of fermentation during ensiling and dry matter content of grass silages on:

1. Chemical composition and nutritive value (measured in vivo and in vitro)

2. Silage quality and the amount and type of fermentation products

3. Performance evaluation of grass silages, varying in fermentation products and dry matter, as dietary ingredients in a feeding trial with dairy cows.

Alongside this experiment a comparative study was performed with rumen cannulated dairy cows to investigate the influence of these rations on rumen fermentation characteristics (fermentation pattern, degradability and kinetics). The results of the rumen studies will be reported in a subsequent paper (de Visser et al., 1992).

\section{Materials and methods}

On August 30th and September 1st three types of grass silage were made from previously cut pastures, one was a strongly wilted grass silage, the other two were high moisture silages with additives (cane molasses or formic acid). After mowing, one quarter of each pasture was dried to approximately 22 to $25 \%$ dry matter in 
an attempt to avoid seepage losses. The grass was tedded once prior to harvesting. During harvesting molasses (MGS) was applied at a rate of approximately $40 \mathrm{~kg}$ per tonne fresh grass. The second quarter of each pasture was harvested at the same time and ensiled with addition of formic acid (6 litres per tonne fresh grass) (FGS). The remaining half of each pasture was wilted to a dry matter content of approximately 45 to $50 \%$ and ensiled without an additive (WGS). The grass was wilted for 36 to $40 \mathrm{~h}$. All silages were harvested with a precision chop harvester and ensiled in long small drive-over silos. Each silo was sealed with two layers of plastic sheeting.

The grass was cut at approximately $3000 \mathrm{~kg}$ DM per hectare, consisted of approximately $95 \%$ of Lolium perenne and was fertilized after the previous cut with $80 \mathrm{~kg} \mathrm{~N} \mathrm{ha}^{-1}$.

During the first 13 weeks of lactation a feeding trial was performed with 56 dairy cows. The animals, Dutch Friesian or Dutch Friesian $\times$ Holstein breed, were in second (approx. $60 \%$ ) or later lactation. A blocked experimental design was used. Each block consisted of four animals grouped in accordance with their previous lactation performances. Within each block the animals were allocated at random to one of the four treatment groups. The animals were kept in a loose housing system with Calan electronic feeding doors.

The basal diet, supplying $70 \%$ of the total dry matter, consisted of maize silage, ensiled pressed beet pulp, moist ensiled maize gluten feed, moist ensiled brewers' grains and concentrates. The remaining $30 \%$ of the diet was composed of wilted grass silage (WGS), grass silage with molasses (MGS), grass silage with formic acid (FGS), or wilted grass silage with extra water (WW). This water was added during the preparation of the diet. The amount of water added to diet WW was equal to the difference in water content measured between the wilted grass silage (WGS) and the grass silage with molasses (MGS). The dietary compositions are given in Table 1. All diets were fed as totally mixed rations (mixer/forage wagon) to avoid selection and fed at $5.00 \mathrm{~h}(40 \%)$ and $15.00 \mathrm{~h}(60 \%)$ respectively. The animals were fed individually and feed refusals recorded daily.

The ingredients contained in the concentrate mixture are listed in Table 2. Pressed beet pulp, moist ensiled maize gluten feed, moist ensiled brewers' grains and concentrates were sampled once a week and analyzed for dry matter (DM) content. The grass and maize silages were sampled twice weekly and analyzed for DM. These weekly samples were subsampled over a monthly period. These monthly samples were analyzed for ash, nitrogen, crude fat, crude fibre, neutral detergent fibre (NDF), starch and sugars, as described earlier (de Visser \& Hindle, 1990). Grass silages, maize silage and ensiled moist by-product feedstuffs were regularly analyzed for volatile fatty acids, alcohols, lactic acid, ammonia and $\mathrm{pH}$ to enable corrections to dry matter content and energy value due to losses of volatile components. The analytical methods used for volatile fatty acids, alcohols, lactic acid and ammonia were as described by Robinson et al. (1986).

The in vitro OM-digestibility was determined for all dietary components using the Tilley \& Terry method (1963), as modified by van der Meer (1980). In vivo digestibility of the grass silages was also measured, using wethers fed at mainte- 
Table 1. Composition of the diets ( $\mathrm{g}$ per kg dry matter).

Ingredient

Wilted grass silage

Grass silage (molasses)

Grass silage (formic acid)

Maize silage

Pressed beet pulp (ensiled)

Maize gluten feed (ensiled)

Brewers' grains (ensiled)

Concentrates

\begin{tabular}{llll} 
Group & & & \\
\hline WGS & MGS & FGS & WW $^{1}$ \\
300 & - & - & 300 \\
- & 300 & - & - \\
- & - & 300 & - \\
140 & 140 & 140 & 140 \\
200 & 200 & 200 & 200 \\
150 & 150 & 150 & 150 \\
100 & 100 & 100 & 100 \\
110 & 110 & 110 & 110
\end{tabular}

${ }^{1}$ Group WW received extra water, which was added to the complete diet.

Table 2. Composition of the concentrate mixture.

\begin{tabular}{ll}
\hline Ingredient & g per kg \\
& \\
Coconut expeller & 405 \\
Soya bean hulls & 100 \\
Linseed expeller & 200 \\
Soya bean meal (solv. extr.) & 145 \\
Fat (animal) & 33 \\
Molasses (cane) & 40 \\
Calcium carbonate & 17 \\
Vitamins and minerals & 20 \\
Salt (NaCl) & 20 \\
Magnesium oxide & 20
\end{tabular}

nance, according to the method described by van Es \& van der Meer (1980). The energy values of the grass silages were calculated, using the in vivo digestibility measurements. These energy values were corrected for losses of volatiles using two methods. In the first method the energy of the volatiles was assumed to be $100 \%$ digestible grass silage OM, while in the second method the energy value was calculated using the individual energy values for the constituent volatile components as published in the Dutch Feed Table (CVB, 1991a).

Milk production was recorded at four consecutive milkings, using a Tru tester (Moderniek bv, Soest). Subsamples were taken in which the fat-, protein- and lactose contents were analyzed (Stichting Melkcontrole Station Noord, the Netherlands). Animals were weighed twice weekly to record bodyweight and calculate bodyweight changes during the experiment. Net energy intake, net energy requirement for maintenance and milk production and body weight change were used to calculate energy balance according to the Dutch net energy system (van Es, 1978). 
Animal performances were also used to compare the digestible crude protein (dcp) and the Duodenal digestible protein systems (DVE) (van Straalen \& Tamminga, 1991). The DVE values of the roughages, moist ensiled by-product ingredients and concentrates were calculated according to equations (Anonymous, CVB nr7, 1991b) and values recorded in the Dutch Feeding Table (Anonymous, CVB, 1991a). All resulting data were subjected to statistical analysis for a blocked experimental design (Genstat; Alvey et al., 1982).

\section{Results}

The chemical composition of the various grass silages is shown in Table 3 . WGS silage showed the lowest ash- and highest cell wall contents (crude fibre, NDF). Sugar content was highest in FGS and lowest in MGS. The concentration of volatile components differed between silages. A relatively large proportion of the organic matter consisted of volatiles in MGS silage, compared to WGS and FGS (Table 4). The in vivo and in vitro OM-digestibility did not differ between silages. The results from both methods showed a high degree of correlation $\left(R^{2}=0.99\right)$.

The in vivo digestibilities of nitrogen, crude fibre, crude fat, NDF and N-free extract did not differ between silages (Table 5). According to the Dutch Net Energy system the calculated net energy values differed between grass silages, when volatiles were calculated as $100 \%$ digestible OM of grass silage (first method), but were similar when using individual energy values for volatile components (Anonymous, 1991b) (second method) (Table 6). The protein values of the grass silages were calculated as dcp as well as DVE and are shown in Table 6. The dcp values were similar for all silages, but DVE values were highest in WGS silage and lowest in MGS silage.

Average dry matter content in the four TMR rations were 399, 336, 331, $336 \mathrm{~g}$ per $\mathrm{kg}$ for WGS, MGS, FGS and WW diets respectively.

Table 3. Chemical composition and in vitro digestibility of the dietary components ( $g$ per $\mathrm{kg}$ dry matter).

\begin{tabular}{llllllllll}
\hline Ingredient & DM $^{1}$ & ash & $\mathrm{N}$ & $\mathrm{CF}$ & cfat & NDF & starch & sugar & vitro \\
Grass silages & & & & & & & & & \\
Wilted & $456 \pm 49$ & $113 \pm 13$ & $30 \pm 4$ & $268 \pm 14$ & $39 \pm 3$ & $492 \pm 20$ & - & $26 \pm 12$ & $73 \pm 1$ \\
Molasses & $246 \pm 28$ & $156 \pm 11$ & $31 \pm 1$ & $222 \pm 6$ & $42 \pm 3$ & $412 \pm 9$ & - & $13 \pm 2$ & $73 \pm 1$ \\
Formic acid & $233 \pm 26$ & $146 \pm 16$ & $32 \pm 3$ & $229 \pm 11$ & $46 \pm 2$ & $429 \pm 20$ & - & $41 \pm 8$ & $73 \pm 1$ \\
Maize silage & $269 \pm 11$ & $57 \pm 6$ & $13 \pm 1$ & $227 \pm 12$ & $25 \pm 1$ & $453 \pm 17$ & $259 \pm 5$ & - & $71 \pm 1$ \\
Beet pulp & $213 \pm 11$ & $86 \pm 16$ & $16 \pm 1$ & $196 \pm 5$ & - & $530 \pm 19$ & - & $13 \pm 4$ & $87 \pm 1$ \\
Maize gluten f. & $401 \pm 19$ & $61 \pm 1$ & $34 \pm 1$ & $103 \pm 11$ & $22 \pm 1$ & $435 \pm 14$ & $168 \pm 15$ & $10 \pm 2$ & $88 \pm 1$ \\
Brewers' grains & $229 \pm 17$ & $53 \pm 8$ & $44 \pm 4$ & $161 \pm 18$ & $100 \pm 8$ & $614 \pm 40$ & $22 \pm 4$ & - & $56 \pm 2$ \\
Concentrates & $898 \pm 6$ & $139 \pm 12$ & $37 \pm 1$ & $127 \pm 5$ & $83 \pm 5$ & $360 \pm 16$ & $17 \pm 6$ & $88 \pm 7$ & $80 \pm 1$ \\
\hline
\end{tabular}

Maize gluten f. $=$ ensiled moist maize gluten feed. Beet pulp $=$ ensiled pressed beet pulp. Brewers'grains $=$ ensiled brewers'grains. $456 \pm 49=456$ and a standard deviation of 49 . vitro = modified Tilley and Terry in vitro digestibility. ${ }^{1}$ Ensiled products corrected for losses due to volatile components. 
Table 4. Volatile components in grass silage ( $g$ per $\mathrm{kg} \mathrm{DM}$ ) and $\mathrm{pH}$.

\begin{tabular}{llllrrr}
\hline Grass silage & $\mathrm{pH}$ & ac & but & lact & $\mathrm{NH}_{3}$ & alc \\
Wilted (WGS) & 4.22 & 10.3 & 0.2 & 36.1 & 10 & 2.2 \\
Molasses (MGS) & 3.98 & 18.4 & 0.2 & 118.6 & 8 & 7.2 \\
Formic acid (FGS) & 4.15 & 19.4 & 2.0 & 25.8 & 5 & 6.5 \\
\hline
\end{tabular}

ac $=$ acetic acid; prop $=$ propionic acid; but $=$ butyric acid; lact $=$ lactic acid; alc $=$ alcohols; $\mathrm{NH}_{3}=$ Ammonia-nitrogen fraction.

Table 5. In vivo and in vitro digestibility of wilted grass silage and wet grass silages of formic acid $(\%)$, without correction for losses of volatiles.

\begin{tabular}{lccccccc}
\hline Grass silage & vitro & OM & N & CF & $\begin{array}{l}\text { cfat } \\
\text { extract }\end{array}$ & N-free & NDF \\
& & & & & & & \\
Wilted (WGS) & $73 \pm 1$ & $75 \pm 1$ & $75 \pm 1$ & $77 \pm 3$ & $64 \pm 1$ & $74 \pm 1$ & $73 \pm 3$ \\
Molasses (MGS) & $73 \pm 1$ & $75 \pm 1$ & $75 \pm 1$ & $77 \pm 4$ & $63 \pm 1$ & $75 \pm 1$ & $72 \pm 3$ \\
Formic acid (FGS) & $73 \pm 1$ & $75 \pm 1$ & $74 \pm 1$ & $78 \pm 4$ & $68 \pm 1$ & $75 \pm 1$ & $72 \pm 3$
\end{tabular}

vitro $=$ in vitro Tilley $\&$ Terry $(1963)$, modified IVVO (1980). cfat $=$ petroleum ether $40: 60^{\circ} \mathrm{C}$. $75 \pm 1=75$ and a standard deviation of 1 .

Table 6. Net energy values (MJ per kg DM), dep and DVE values ( $g$ per $\mathrm{kg} \mathrm{DM}$ ) of wilted grass silage, high moisture grass silage with molasses or formic acid.

\begin{tabular}{lllll}
\hline \multirow{2}{*}{ Grass silage } & \multicolumn{2}{l}{ Net energy values } & \multirow{2}{*}{ dcp } & DVE \\
\cline { 2 - 3 } & Method 1 & Method 2 & & \\
Wilted (WGS) & 5.86 & 5.70 & 141 & 68 \\
Molasses (MGS) & 5.83 & 5.30 & 146 & 47 \\
Formic acid (FGS) & 5.63 & 5.41 & 148 & 52 \\
\hline
\end{tabular}

Energy value correction for volatile components: Method 1: volatiles assumed $100 \%$ digestible and allocated an average energy value for OM; Method 2: volatiles assumed $100 \%$ digestible and allocated individual energy values per component, in accordance with CVB Table, 1991. dcp = digestible crude protein. DVE $=$ Duodenal digestible protein .

Feed intake and milk performance results are shown in Table 7. Total dry matter intake was significantly lower on both high moisture grass silage diets (MGS, FGS), compared to diets WGS and WW, as was the Dutch net energy (using the second method) and protein intake (dcp, DVE). Milk production was highest for cows fed WGS and WW. Milk fat percentage and production did not differ between treatments. Milk protein production was significantly lower on both of 
Table 7. Daily feed intake, milk production, milk composition and bodyweight for the 13 week experimental period (mean of 14 animals)

\begin{tabular}{lccccc}
\hline & WGS & MGS & FGS & WW & SED \\
Total DM intake (kg) & $21.9^{\mathrm{a}}$ & $19.6^{\mathrm{b}}$ & $20.0^{\mathrm{b}}$ & $21.0^{\mathrm{a}}$ & 0.53 \\
grass silage (kg) & 6.5 & 6.0 & 6.1 & 6.3 & 0.15 \\
Net energy intake (MJ) $)^{1)}$ & $143^{\mathrm{a}}$ & $130^{\mathrm{b}}$ & $129^{\mathrm{b}}$ & $137^{\mathrm{a}}$ & 3.74 \\
dcp intake (g) & $2664^{\mathrm{a}}$ & $2466^{\mathrm{b}}$ & $2533^{\mathrm{b}}$ & $2570^{\mathrm{a}}$ & 74.0 \\
DVE intake (g) & $1894^{\mathrm{a}}$ & $1573^{\mathrm{b}}$ & $1636^{\mathrm{b}}$ & $1816^{\mathrm{a}}$ & 65.0 \\
Milk (kg) & $35.9^{\mathrm{a}}$ & $34.3^{\mathrm{b}}$ & $34.4^{\mathrm{b}}$ & $35.8^{\mathrm{a}}$ & 0.64 \\
Fat (g) & 1640 & 1570 & 1572 & 1664 & 67.8 \\
Protein (g) & $1152^{\mathrm{a}}$ & $1077^{\mathrm{b}}$ & $1080^{\mathrm{b}}$ & $1138^{\mathrm{a}}$ & 24.7 \\
Lactose (g) & $1680^{\mathrm{a}}$ & $1581^{\mathrm{b}}$ & $1592^{\mathrm{b}}$ & $1682^{\mathrm{a}}$ & 32.8 \\
Fat (\%) & 4.57 & 4.58 & 4.57 & 4.65 & 0.16 \\
Protein (\%) & 3.21 & 3.14 & 3.14 & 3.18 & 0.05 \\
Lactose (\%) & $4.68^{\mathrm{ac}}$ & $4.61^{\mathrm{b}}$ & $4.63^{\mathrm{bc}}$ & $4.70^{\mathrm{a}}$ & 0.03 \\
PFCM (kg) & $38.0^{\mathrm{a}}$ & $36.2^{\mathrm{b}}$ & $36.2^{\mathrm{b}}$ & $38.1^{\mathrm{a}}$ & 1.02 \\
Energy intake/req.ratio & $91^{\mathrm{a}}$ & $86^{\mathrm{b}}$ & $86^{\mathrm{b}}$ & $87^{\mathrm{b}}$ & 2.49 \\
Energy intake/req.ratio & $90^{\mathrm{a}}$ & $83^{\mathrm{b}}$ & $84^{\mathrm{b}}$ & $86^{\mathrm{b}}$ & 2.13 \\
dcp intake/req.ratio & 97 & 93 & 96 & 96 & 2.90 \\
DVE intake/req.ratio & $103^{\mathrm{a}}$ & $94^{\mathrm{b}}$ & $97^{\mathrm{ab}}$ & $102^{\mathrm{a}}$ & 2.50 \\
Bodyweight (kg) & 607 & 588 & 581 & 616 & 19.0 \\
Bodyweight loss (g) & 290 & 460 & 440 & 450 & 70.6 \\
\hline
\end{tabular}

Figures with a different superscript differ significantly $(P<0.05)$. Energy intake $=$ Intake in Net

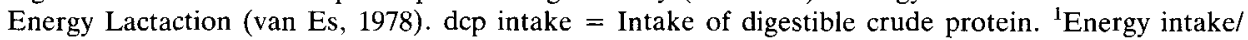
req.ratio $=$ intake $/$ requirement ratio $(\%)$ calculated with individual energy values of volatiles. ${ }^{2}$ Energy intake/req.ratio $=$ intake $/$ requirement ratio $(\%)$ calculated with average energy value of OM. dep intake/req.ratio $=$ intake $/$ requirement ratio $(\%)$. DVE intake/req.ratio $=$ intake/ requirement ratio $(\%) . \mathrm{PFCM}=$ Protein and fat corrected milk. SED $=$ standard error of difference.

the high moisture silages (MGS, FGS), while milk protein percentage tended to be lower on treatments MGS and FGS, than WGS. Milk production corrected for fat and protein content (PFCM) was lowest on MGS and FGS. All treatments showed a calculated negative net energy balance for the duration of the trial.

\section{Discussion}

Although the ash content in the silages was approximately $140 \mathrm{~g}$ per $\mathrm{kg} \mathrm{DM}$ and as such relatively high, the values fell within the range accepted for autumn grown grass silages (100-155 $\mathrm{g}$ per $\mathrm{kg} \mathrm{DM}$ ), as found in commercially analysed field tests in the Netherlands (Van Dijk; Bedrijfslaboratorium voor Grond- en Gewasonderzoek, pers. comm).

The comparatively lower ash content found in WGS as opposed to the other grass silages (MGS, FGS) was probably caused by the removal of excess soil (ash) 
during the wilting process. Ash content in MGS silage was $10 \mathrm{~g}$ per $\mathrm{kg}$ DM higher than that found in FGS silage. This difference in ash content between MGS- and FGS silage could be explained by excess ash present in the molasses, which was added to the MGS silage (Anonymous, 1991b). The higher crude fibre and NDF contents found in WGS silage agreed with results from earlier laboratory studies by van Vuuren et al. (1989). They concluded, that the drying process itself positively influenced NDF levels. Probably, due to inducing the formation of a nitrogen sugar complex (Maillard reaction).

MGS silage contained higher amounts of fermentation end-products compared to WGS and FGS silage, which was in agreement with results from Donaldson \& Edwards (1976) and Murphy \& Gleeson (1984). This was reflected in the lower amount of sugars measured in MGS silage, in spite of the higher sugar content of MGS silage at the time of ensiling (grass and molasses). Although 6 liters of formic acid were added per ton fresh grass in FGS silage a relatively large proportion of fermentation end products could still be measured, in comparison with the MGS silage, this was in disagreement with Hinks \& Henderson (1984).

Several researchers reported lower energy values, as well as higher concentrations of butyric acid in wilted silage compared to wet ensiled grass silage made with an additive (formic acid) (Gordon, 1989; Zimmer \& Wilkins, 1984). However, the results of these experiments showed large differences in duration of wilting, weather conditions (temperature, rainfall, etc.) and increased DM-content as a result of wilting compared to our experiment. Under poor weather conditions the use of formic acid had a positive influence on the quality of wilted grass silage (Gordon, 1989; Zimmer \& Wilkins, 1984). When comparing wilted silages with high moisture silages ensiled using an additive the weather conditions should be taken into account, because it is evident that poor weather conditions have a negative influence on the results.

The in vitro and in vivo OM-digestibilities were highly correlated and fell well within the range of reported results (Burgstaller \& Huber, 1984; Donaldson \& Edwards, 1976; Murphy \& Gleeson, 1984 and Steg et al., 1990). The in vivo digestibilities of nitrogen, crude fibre, crude fat, NDF and $\mathrm{N}$-free extract were similar for all silages (Table 5) and agreed with the results of Burgstaller et al. (1984) and Steg et al. (1990).

The energy values of the grass silages were substantially influenced by the calculation method employed to estimate the energy value of the volatiles (Table 6). Energy values are under-estimated (first method), when grass silages contain large quantities of volatiles, especially alcohols. This observation agreed with Zimmer \& Wilkins (1984), reviewing data of various experiments comparing wilted to wet silages. They also concluded that energy values as well as DM content will be under-estimated when alcohols and volatiles form a substantial part of the dry matter.

Although $70 \%$ of the total ration was similar for all diets, the DM intake on both high moisture grass silages (MGS, FGS) was significantly lower, compared to WGS and WW. These findings agreed with the results found by Burgstaller \& Huber (1984), Gordon (1980) and Zimmer \& Wilkins (1984), when comparing wilted grass silage to high moisture grass silage diets. The tendency towards lower 
DM intake by group WW and the significantly lower DM intake on MGS and FGS as compared to WGS agreed with earlier findings of Lahr et al. (1983) and de Visser et al. (1987, 1990). They found a negative relationship between the dry matter content of total rations and DM intake, when DM content was below $40 \%$. Total DM intake seemed to be related to total dry matter content (WW) as well as to dry matter content and fermentation end products present in grass silages (MGS, FGS). The first seemed more related to the capacity of the cow to consume large quantities of food in early lactation (bulk), while a combination of lower DM content and higher amounts of fermentation end products seem to reduce the DM intake more permanently.

The lower DM intake on cows fed MGS and FGS diets resulted in lower net energy (second method) and protein (dcp, DVE) intakes, which negatively affected milk yield and milk protein quantity (Table 7).

The animals fed MGS and FGS diets mobilized more energy reserves, which was reflected in a larger body weight loss (Table 7). During this period more long chain fatty acids were mobilized from adipose tissue. Probably, these extra long chain fatty acids were efficiently incorporated into milk fat by the mammary gland (Palmquist \& Conrad, 1971; Vernon, 1988), compensating the lower energy intake. As a result milk fat content and productions did not differ significantly between diets.

The lower rumen digestible OM intake (Table 5; Table 7), the increased mobilisation of body reserves (long chain fatty acids; Table 7) and the reduced protein intake (DVE) (Table 7) resulted in lower glucogenic/ketogenic and aminogenic/ketogenic nutrient ratios for cows fed high moisture silage diets (MGS, FGS), which probably resulted in a reduction of glucose and amino acids available for milk lactose and milk protein production (Vernon, 1988). This was reflected in a significantly lower milk production (lactose) as well as lower milk protein output. These results agreed with those of Broster \& Thomas (1981), who also observed a lower milk protein content, when feeding below energy and protein requirements. The lower calculated DVE intakes on MGS and FGS diets agreed with the lower milk protein production and protein content and support the hypothesis of reduced microbial protein synthesis, which was reflected in higher concentrations of ammonia and branched chain fatty acids (BCFA) and valerate found in the rumen fluid of cannulated dairy cows fed the same diets (de Visser et al., 1992). These higher concentrations also agreed with previous results, in which lower microbial protein synthesis was measured in relation to increased concentrations of ammonia, BCFA and valerate (de Visser et al., 1987, 1991; Robinson et al., 1987). However, our results disagree with those of Peoples \& Gordon (1989), Steen \& Gordon (1980), Gordon \& Peoples (1986) and Zimmer $\&$ Wilkins (1984), who found similar milk protein outputs, when feeding wilted or high moisture grass silages. The discrepancy between our results and the literature mentioned, might be explained by differences in the fed supplement.

In our experiment the grass silages were supplemented with by-products, partly consisting of moist ensiled products (Table 1). The supplements referred to in the literature consisted mainly of barley and soya bean meal. The amount of rumen 
fermentable carbohydrates, starch and sugars, was relatively low in our experiment (Table 3). However, when feeding supplements containing large quantities of barley a substantial amount of the carbohydrates became rapidly available for rumen fermentation, thus compensating for the loss of easily fermentable carbohydrates during the ensiling process of high moisture grass silages into fermentation end products. As a result a larger amount of nitrogen, available as ammonia in the rumen after degradation of grass silage protein, might be incorporated into microbial protein (van Straalen \& Tamminga, 1990, Nocek \& Russell, 1988). The new Dutch protein system (DVE, van Straalen \& Tamminga, 1991) proved to be more accurate in predicting protein balance of WGS and WW than was the dcp system (Table 7). However, it was less accurate for moist ensiled grass silage made with an additive. The equations for grass silage used in the Dutch DVE system were derived from wilted grass silage data (W.M. van Straalen, pers. comm.), which might explain the difference found in this experiment.

Body weight changes on both the moist treatments (MGS, FGS) did not correspond with the energy balances calculated according to the Dutch net energy system (van Es, 1978), using energy values for volatiles as $100 \%$ digestible grass silage OM (first method). Yet when the energy values for individual volatile components (CVB Table, anonymous, 1991) were used to calculate net energy intake (second method) and net energy balance, they compared more favourably with the observed changes in body weight.

The ensiling method influenced total dry matter- and energy intake, as well as milk production. The energy values of grass silages should be calculated using individual energy values for volatiles. The type of supplement used, should be optimized allowing for rumen fermentable carbohydrates to avoid negative influences on milk protein output.

\section{Acknowledgements}

The authors would like to thank Messrs L. de Jong, J. Truin and W. Bakker for taking care of the dairy cows during the feeding trial and $\mathrm{Mr} \mathrm{R}$. Terluin and his staff for performing the digestibility trials with wethers. The authors also appreciate the financial support of the Institute for Rational Sugar production (IRS), ZBB-Amylum and Bonda and for the provision of the moist ensiled by-products (beet pulp, maize gluten feed and brewer's grains) by these companies.

\section{References}

Alvey, N., N. Galway \& P. Lane, 1982. An introduction to Genstat. Academic Press, London, 152 pp.

Anonymous, 1991a. Dutch Feeding Table. (In Dutch). Centraal Veevoederbureau in Nederland, Lelystad.

Anonymous, 1991b. Protein valuation for ruminants: the DVE-system, CBV no. 7. (In Dutch). Centraal Veevoederbureau in Nederland, Lelystad.

Broster, W. H. \& C. Thomas, 1981. The influence of level and pattern of concentrate input on milk output. In: W. Haresign (Ed.), Recent advances in animal nutrition, p. 49-69. Butterworths, 
Londen.

Burgstaller, G. \& A. Huber, 1984. Zum Verzehr von Silage aus Mahweidegras unterschiedlichen Anwelkgrades durch Milchkühe. Das Wirtschaftseigene Futter 30: 149-158.

Castle, M. E. \& J. N. Watson, 1970a. Silage and milk production: a comparison between wilted and unwilted grass silages made with and without formic acid. Journal of the British Grassland Society 25: $65-70$.

Castle, M. E. \& J. N. Watson, 1970b. Silage and milk production: a comparison between wilted and unwilted grass silages made with and without formic acid. Journal of the British Grassland Society 25: $278-283$.

Derbyshire, J. C., C. H. Gordon \& D. R. Waldo, 1976. Formic acid as a silage preservative for milking cows. Journal of Dairy Science 59: 278-287.

Donaldson, E. \& R. A. Edwards, 1976. Feeding value of silage: silages made from freshly cut grass, wilted grass and formic acid treated wilted grass. Journal Science of Food and Agriculture 27: 536-544.

Es, A. J. H. van, 1978. Feed evaluation for ruminants. 1. The system in use from May 1977 onwards in the Netherlands. Livestock Production Science 5: 331-335.

Es, A. J. H. van \& J. M. van der Meer, 1980. Methods of analysis for predicting the energy and protein value of feeds for farm animals. In: Proceedings of workshop of methodology of analysis of feedstuff for ruminants, Lelystad, the Netherlands.

Gordon, F. J., 1980, The effect of interval between harvests and wilting on silage for milk production. Animal Production 31: 35-41.

Gordon, F. J., 1989. Effect of silage additives and wilting on animal performance. In: W. Haresign \& D. J. A. Cole (Eds.), Recent advances in animal nutrition, p. 159-173. Butterworth, London.

Gordon, F. J. \& A. C. Peoples, 1986. The utilization of wilted and unwilted silages by lactating cows and the influence of changes in the protein and energy concentration of the supplement offered. Animal Production 43: 355-366.

Hinks, C. E. \& A. R. Henderson, 1984. Efficiency of silage systems: a comparison between unwilted and wilted silages. In: E. Zimmer \& R. J. Wilkins (Eds), Eurowilt. Landbauforschung Völkenrode, Sonderheft 69: 18-20.

Honig, H., K. Rohr \& R. Daenicke, 1984. Efficiency of silage systems: a comparison between wilted silages. In: E. Zimmer \& R. J. Wilkins (Eds), Eurowilt. Landbauforschung Völkenrode, Sonderheft 69: 39-41.

Lahr, D. A., D. E. Otterby, D. G. Johnson, J. G. Linn \& G. Lundquist, 1983. Effects of moisture content of complete diets on feed intake and milk production by cows. Journal of Dairy Science 66: 1891-1900.

Meer, J. M. van der, 1980. Determination of the in vitro digestibility coefficient of feeds for ruminants. Report No. 67, ... pp. IVVO, Lelystad.

Miller, E. L., 1982. The nitrogen needs of ruminants. Occasional Publication of the British Society of Animal Production 6: 79-88.

Murphy, J. J. \& P. A. Gleeson, 1984. Effect of wilting and formic acid treatment on silage preservation and performance of autumn-calving cows. Irish Journal of Agricultural Research 23: 105-116.

Nocek, J. E. \& J. B. Russell, 1988. Protein and energy as an integrated system. Relationship of ruminal protein and carbohydrate availability to microbial synthesis and milk production. Journal of Dairy Science 71: 2070-2107.

Palmquist, D. L. \& H. R. Conrad, 1971. Origin of plasma fatty acids in lactating cows fed high grain or high fat diets. Journal of Dairy Science 54: 1025-1033.

Peoples, A. C. \& F. J. Gordon, 1989. The influence of wilting and season of silage harvest and the fat and protein concentration of the supplement on milk production and food utilization by lactating cattle. Animal Production 48: 305-317.

Robinson, P. H., S. Tamminga \& A. M. van Vuuren, 1986. Influence of declining level of feed intake and varying the proportion of starch in the concentrate on rumen fermentation in dairy cows. Livestock Production Science 15: 173-189.

Robinson, P. H., S. Tamminga \& A. M. van Vuuren, 1987. Influence of wet versus dry by-product ingredients and addition of branched chain fatty acids and valerate to dairy cows. 2 . Rumen fermentation and milk production. Netherlands Journal of Agricultural Science 35: 459-471. 


\section{H. DE VISSER AND V. A. HINDLE}

Soest, P. J. van, 1982. Nutritional ecology of the ruminant. O \& E books, Corvallis, Oregon, USA, $374 \mathrm{pp}$.

Steen, R. W. J. \& F. J. Gordon, 1980. The effect of type of silage and level of concentrate supplementation offered during early lactation on total lactation performance of January/February calving cows. Animal Production 30: 341-354.

Steg, A., S. F. Spoelstra, J. M. van der Meer \& V. A. Hindle, 1990. Digestibility of grass silage. Netherlands Journal of Agricultural Science 38: 407-422.

Straalen, W. M. van \& S. Tamminga, 1990. Protein degradation of ruminant diets. In: J. Wiseman \& D. J. A. Cole (Eds), Feedstuff evaluation, p.55-72. Butterworths, London.

Tilley J. M. \& R. E. Terry, 1963. A two-stage technique for the in vitro digestion of forage crops. Journal of the British Grassland Society 18: 104-111.

Vernon, R. G., 1988. The partition of nutrients during the lactation cycle. In: P. C. Garnsworthy (Ed.), Nutrition and lactation in the dairy cow, p. 32-52. Butterworths, London.

Visser. H. de \& V. A. Hindle, 1990. Dried beet pulp, pressed beet pulp and maize silage as substitutes for concentrates in dairy cow rations. 1. Feeding value, feed intake, milk production and milk composition. Netherlands Journal of Agricultural Science 38: 77-88.

Visser, H. de, H. Huisert, P. L. van der Togt \& A. Klop, 1992. Autumn-cut grass silage as roughage component in dairy cow rations. 2. Rumen fermentation and degradability. Netherlands Journal of Agricultural Science 40: (in press)

Visser, H. de \& S. Tamminga, 1987. Influence of wet versus dry by-product ingredients and addition of branched chain fatty acids and valerate to dairy cows. 1. Feed intake, milk production and milk composition. Netherlands Journal of Agricultural Science 35: 163-175.

Vuuren, A. M. van, K. Bergsma, F. Krol-Kramer \& J. A. C. van Beers, 1989. Effects of addition of cell wall degrading enzymes on the chemical composition and the in sacco degradation of grass silage. Grass and Forage Science 44: 223-230.

Zimmer, E \& R. J. Wilkins, 1984. Efficiency of silage systems: a comparison between unwilted and wilted silages. In: E. Zimmer \& R. J Wilkins (Eds), Eurowilt. Landbauforschung Völkenrode, Sonderheft 69: 71-72. 